\title{
Dynamics of Dissolved Organic Carbon in Forested and Disturbed Catchments, Westland, New Zealand 1. Maimai
}

\author{
T. R. MOORE
}

\author{
Department of Geography, McGill University, Montreal, Quebec, Canada
}

\begin{abstract}
Dissolved organic carbon (DOC) dynamics were investigated in 2 undisturbed catchments (beechpodocarp-hardwood forest) and 6 catchments which had been clear-cut 8-10 years previously and planted with pine. Over a 4-month sampling period, DOC concentrations in an undisturbed catchment averaged $1.4,16.0,356.0$, and $55.7 \mathrm{mg} / \mathrm{L}$ in precipitation, throughfall, stemflow, and surface organic horizon, respectively. DOC concentrations decreased to averages of 11.8 and $4.5 \mathrm{mg} / \mathrm{L}$ in the subsoil and stream, respectively. The annual flux of DOC was estimated as an input through precipitation of $3.4 \mathrm{~g} / \mathrm{m}^{2}, 83.6 \mathrm{~g} / \mathrm{m}^{2}$ through the organic horizon, and an export of $6.8 \mathrm{~g} / \mathrm{m}^{2}$ in the stream. The pronounced decrease in DOC concentration and flux in the subsoil horizon is related to the high concentrations of amorphous, oxalate-extractable $\mathrm{Fe}$, and $\mathrm{Al}$ with high $\mathrm{DOC}$-adsorption capacities. In streams draining the 8 catchments, discharge-weighted DOC concentrations ranged from 4.5 to 10.2 $\mathrm{mg} / \mathrm{L}$. DOC and log discharge showed a significant positive relationship and the rising limb of the storm hydrograph contained higher DOC concentrations than the falling limb, at similar discharges. Export of DOC in 1986 ranged from 8 to $21 \mathrm{~g} / \mathrm{m}^{2}$ and was related to the type of disturbance: the lowest values were recorded in undisturbed catchments and the highest in catchments that had been clear-cut and the slash had not been burnt. Organic debris in the stream channel appear to be important sources of stream DOC and probably account for the higher DOC concentrations in the disturbed catchments, 8-10 years after disturbance.
\end{abstract}

\section{INTRODUCTION}

Dissolved organic carbon (DOC) is an important feature of water quality. It can make a significant contribution to the acidity of natural waters through organic acids [e.g., Eshleman and Hemond, 1985; Kerekes et al., 1986; Oliver et al., 1983] and biological activities through the absorption of light [e.g., Davies-Colley and Vant, 1987]. By formation of organic complexes, DOC can influence nutrient availability [e.g., Stewart and Wetzel, 1981] and control the solubility, transport, and toxicity of metals [e.g., Reuter and Perdue, 1977]. Although a considerable amount of information exists on the export of DOC in streams [e.g., Schlesinger and Melack, 1981], less is known about the sources and sinks of DOC within vegetation-soil systems [e.g., McDowell and Wood, 1984; Thurman, 1985].

The effect of disturbance on fluxes of water, sediments, and nutrients within forested catchments has been studied intensively, but little is known of the effects of disturbance on fluxes of DOC. The findings of three studies on the role of forest clear-cutting on DOC export from small catchments are contradictory. In the Hubbard Brook Experimental Forest, New Hampshire, Hobbie and Likens [1973] reported no major change in DOC export from undisturbed and clear-cut catchments, 2-4 years after clear-cutting. At the Coweeta Hydrological Laboratory, North Carolina, Meyer and Tate [1983] observed a $28 \%$ decrease in DOC export from a catchment clear-cut 2 years previously, compared to an undisturbed catchment. In the H. J. Andrews Forest, Oregon, Dahm [1980] noted a 53\% increase in DOC export over 2 years in a clear-cut catchment, compared to an undisturbed catchment. DOC movement within, and export

Copyright 1989 by the American Geophysical Union.

Paper number 89WR00343.

0043-1397/89/89WR-00343\$05.00 from, small catchments involves a range of biological and hydrological processes [Meyer and Tate, 1983; Tate and Meyer, 1983], whose importance varies between catchments and with degree and type of disturbance.

The purposes of this and the following paper [Moore and Jackson, this issue] are (1) to monitor the concentrations and fluxes of DOC in several forested catchments in New Zealand and to determine the major controlling factors; (2) to evaluate the effect of disturbance, such as clear-cutting or drainage on DOC export; and (3) to investigate the contribution of DOC to stream water acidity.

In the first paper, the Maimai set of catchments are examined. These are eight small, steep, well-drained catchments; two retain the original forest cover, while the other six have been clear-cut with different forest management practices and planted to pine.

\section{STUDY SITE}

The eight Maimai catchments were established by the New Zealand Forest Service in the Tawhai State Forest near Reefton, North Westland, South Island, New Zealand $\left(42^{\circ} 05^{\prime} \mathrm{S}\right.$, $171^{\circ} 48^{\prime} \mathrm{E}$ ). They are underlain by firmly compacted, moderately weathered, impermeable Old Man Gravels with silty loam/clay loam soils which are generally shallow $(0.5-1 \mathrm{~m})$ Dystrochrepts and Humults with thick, surface organic horizons [McKie, 1979; Webster, 1977]. The catchments were covered originally by an evergreen forest dominated by beeches (Nothofagus spp.), podocarps, and broadleaf hardwoods. Annual precipitation averages about $2400 \mathrm{~mm}$, distributed evenly throughout the year, producing approximately $1500 \mathrm{~mm}$ of runoff from the catchments, which are very responsive to storm rainfall. Summer temperatures average $16^{\circ} \mathrm{C}$ and drop to $5^{\circ} \mathrm{C}$ in the winter [Ross et al., 1977].

Two of the catchments are in native forest and the remaining six were clear-cut from 1976 to 1978 in a variety of 
TABLE 1. Characteristics of the Eight Experimental Catchments at Maimai

\begin{tabular}{cccc}
\hline Catchment & $\begin{array}{c}\text { Area, } \\
\text { ha }\end{array}$ & $\begin{array}{c}\text { Relief, } \\
\mathrm{m}\end{array}$ & \multicolumn{1}{c}{ Treatment } \\
\hline M5 & 2.31 & 74 & $\begin{array}{c}\text { clear-cut, January 1987; desiccant } \\
\text { sprayed April 1978; planted } \\
\text { July 1979 }\end{array}$ \\
M6 & 1.63 & 85 & $\begin{array}{l}\text { undisturbed } \\
\text { clear-cut September 1976; burned } \\
\text { February 1977; planted August } \\
\text { M7 }\end{array}$ \\
1977
\end{tabular}

treatments to evaluate the effect of forest management techniques on runoff, sediment load, and nutrient export [see Neary et al., 1978; O'Loughlin et al., 1978, 1980, 1982; Pearce et al., 1976, 1980; Pearce and Rowe, 1979]. Slash was either burned or left on the soil surface and in some catchments a riparian strip was left alongside the stream (Table 1). After clear-cutting, the catchments were planted with radiata pine (Pinus radiata) and a few eucalyptus seedlings.

\section{METHODS}

\section{Sample Collection}

Precipitation was collected in a polyethylene funnel with a wad of glass wool to prevent contamination from particulate matter. Throughfall was collected by five $20 \mathrm{~cm}$ diameter polyethylene funnels placed $30 \mathrm{~cm}$ above the forest floor in catchment M6; glass wool was placed in the funnel necks to prevent contamination and changed when dirty. Stemflow was collected by placing a 2-cm-diameter tubing, cut in half, around the stems of 2 miro (Prummopitys ferruginea), 2 hard beech (Nothofagus truncata), 1 rimu (Dacrydium cupressium), and 1 kamahi (Weinmannia racemosa), representing the major species in the forest. The collar channelled stemflow through a wad of glass wool into a 2-L bottle at the base of the tree.

Samples of soil water were collected by vertical placement of ceramic cups in triplicate at depths of $10-15 \mathrm{~cm}$ (topsoil) and $30-40 \mathrm{~cm}$ (subsoil) in a sideslope in catchment M6. Water was drawn into the pots by creating a vacuum with a pump and then siphoned into a plastic bottle.

Collections of the above samples were made at approximately weekly intervals from February to May 1986.

Samples of streamwater from each catchment were collected from the weir at weekly intervals from January to December 1986, and some samples were taken at selected catchments during the rising and falling limbs of storms. Stage height at the V-notch weirs was monitored by water level recorders and converted into discharge, runoff, and a flow duration curve.

\section{Budget Calculations}

DOC export from the catchments was calculated using DOC:discharge relationships and flow:duration data for 1986. Discharge was separated into 51 to 57 classes and the DOC concentration for the middle value of each class was calculated from the regression, converted to export from runoff in each of the classes and summed for the period January 1 to December 31,1986 . As noted by Dann et al. [1986], calculations of ion export are dependent on the methods available, when both discharge and concentration are not monitored continuously. As the DOC concentration and discharge were correlated closely in 5 of the 8 catchments, this stratified regression method probably gives reasonably reliable results [Johnson, 1979].

\section{Laboratory Experiments}

A laboratory study was conducted to establish the adsorption of DOC on soil horizons, following the method outlined by McDowell and Wood [1984]. Four soil samples representing subsoil horizons in the Maimai catchments, plus two subsoil samples from the Larry River catchments [Moore and Jackson, this issue] were collected, air dried, and ground to pass a $2-\mathrm{mm}$ sieve. Five gram samples of the six soils were placed in $100 \mathrm{~mL}$ flasks. To this, $50 \mathrm{~mL}$ of solution was added, being organic-rich Larry River stream water diluted with distilled water to give initial DOC concentrations of $0,10.6,21.2,31.8$, and $42.4 \mathrm{mg} / \mathrm{L}$. The suspensions were shaken by hand for a few minutes over 3 hours and then allowed to stand overnight to equilibrate. After filtering through GF/C paper, DOC was determined on the filtrate, as described below. The Larry River samples gave slightly turbid filtrates, associated with the high silt and clay content of these soils. These samples were filtered through $0.45 \mu \mathrm{m}$ membrane filter before DOC analysis.

Equilibrium concentrations of DOC for each soil sample were estimated by plotting the final DOC concentration against the amount of DOC adsorbed by or released from the soil [Nodvin et al., 1986]. The intercept of the sorption isotherm, where there is no net adsorption or release of DOC, was taken as the equilibrium concentration of DOC.

\section{Analytical Methods}

Samples were analyzed for DOC by the potassium dichromate wet oxidation method, described by Moore [1985], using aliquot sizes ranging from less than $5 \mathrm{~mL}$ for the most organic-rich stemflow samples to $200 \mathrm{~mL}$ for precipitation samples.

Absorbance in a $1-\mathrm{cm}$ cell at $330 \mathrm{~nm}$ was determined on stream water samples to allow the development of regression equations describing DOC and absorbance relationships [Moore, 1987]. This was used to predict DOC concentrations from absorbance measurements for the period June to December 1986. The regression used was

$$
\mathrm{DOC}=45.5 \mathrm{abs}+1.4
$$

where DOC is given in milligrams per liter, abs is absorbance in a $1-\mathrm{cm}$ cell at $330 \mathrm{~nm}, n=146, r^{2}=0.92$, and the standard error of the estimate is given in $0.77 \mathrm{mg} / \mathrm{L}$.

The six soil samples used in the adsorption study were analysed as follows [McKeague, 1978]: soil $p \mathrm{H}$ was determined in $0.01 \mathrm{M} \mathrm{CaCl}_{2}$; soil organic carbon was determined by dichromate digestion; oxalate-extractable iron and alumi- 
num $\left(\mathrm{Fe}_{0}\right.$ and $\mathrm{Al}_{0}$ ) were determined by the acid ammonium oxalate method and pyrophosphate-extractable iron, aluminum, and carbon $\left(\mathrm{Fe}_{\mathrm{p}}, \mathrm{Al}_{\mathrm{p}}\right.$, and $\mathrm{C}_{\mathrm{p}}$ ) by the sodium pyrophosphate method.

\section{RESULTS}

\section{Concentrations and Fluxes of DOC} in an Undisturbed Catchment

Over the 4-month sampling period, average concentrations of DOC were low in precipitation $(1 \mathrm{mg} / \mathrm{L})$, but much higher in throughfall $(16 \mathrm{mg} / \mathrm{L})$ and stemflow $(356 \mathrm{mg} / \mathrm{L})$ under a native forest in catchment M6 (Table 2). Water samples collected from the surface $(10-15 \mathrm{~cm}$ depth) organic soil horizons in catchment M6 averaged $56 \mathrm{mg} / \mathrm{L}$ DOC, about 3 times that observed in throughfall. There was, however, a pronounced decrease in DOC concentrations in subsoil (30-40 cm depth) and streamwater samples, averaging 12 and $5 \mathrm{mg} / \mathrm{L}$, respectively.

In 1986, precipitation at Maimai was $2247 \mathrm{~mm}$, equivalent to about $92 \%$ of the $1975-1986$ average. Runoff in 1986 at the undisturbed M6 and M15 catchments amounted to 111 and $118 \%$, respectively, of the average runoff for 1974-1982. Thus 1986 may be regarded as an average year in relation to hydrologic conditions.

Using estimates of the average annual hydrologic budget of catchment M6 and average DOC concentrations in precipitation, throughfall, stemflow, soil water, and streamwater, a tentative DOC budget was developed. Average annual precipitation at Maimai is about $2400 \mathrm{~mm}$ [Rowe, 1986] and Rowe [1979] estimated that throughfall and stemflow amounted to about 73 and $1.5 \%$ of the precipitation, respectively. Runoff from the M6 catchment averages about $54 \%$ of precipitation (L. K. Rowe, personal communication, 1988).
TABLE 2. A Budget of DOC Fluxes in the Undisturbed Catchment M6 Maimai

\begin{tabular}{lccc}
\hline & $\begin{array}{c}\text { Fluxes of } \\
\text { Water, } \\
\mathrm{mm}\end{array}$ & $\begin{array}{c}\text { DOC } \\
\text { Concentration, } \\
\mathrm{mg} / \mathrm{L}\end{array}$ & $\begin{array}{c}\text { DOC } \\
\text { Flux, g C } \\
\mathrm{m}^{-2} \mathrm{yr}^{-1}\end{array}$ \\
\hline Precipitation & 2400 & 1.4 & 3.4 \\
Throughfall & 1750 & $\begin{array}{c}(0.7,19) \\
16.0\end{array}$ & 28.0 \\
Stemflow & 36 & $(12.3,48)$ & $(1.9)$ \\
& & 356.0 & 12.8 \\
Surface soil & 1500 & $(686.1,57)$ & $(3.7)$ \\
water & 1500 & 55.7 & 83.6 \\
Subsurface soil & $137.6,28)$ & $(2.4)$ \\
water & 1500 & 11.8 & 17.7 \\
Stream & & $(6.7,28)$ & $(3.0)$ \\
& & $(1.7 .5$ & 6.8 \\
& & & $(1.8)$ \\
\hline
\end{tabular}

Budget was based on measurements of DOC concentrations in precipitation, throughfall, stemflow, surface and subsurface soil water, and stream water from February to May 1986 and extrapolated to the rest of the year. Figures in parentheses indicate standard deviation and number of samples analyzed, respectively. Flux of water for each component is based on an average year and estimated contributions of throughfall, stemflow, and runoff.

Using these figures, an annual DOC budget for catchment M6 was developed (Table 2). Inputs of DOC from precipitation were low ( $3.5 \mathrm{~g} \mathrm{DOC}^{-2} \mathrm{yr}^{-1}$ ), but substantial fluxes of DOC were generated as water flowed through the tree canopy (throughfall and stemflow) and into the forest floor, reaching a maximum of $84 \mathrm{~g} \mathrm{~m}^{-2} \mathrm{yr}^{-1}$ in the surface soil horizon. There was a substantial reduction in DOC flux with passage through the subsoil horizons to about $18 \mathrm{~g} \mathrm{~m}^{-2} \mathrm{yr}^{-1}$ and into the stream system, to about $7 \mathrm{~g} \mathrm{~m}^{-2} \mathrm{yr}^{-1}$.

Field observations of DOC immobilization as water passed through subsoil horizons were confirmed in labora-

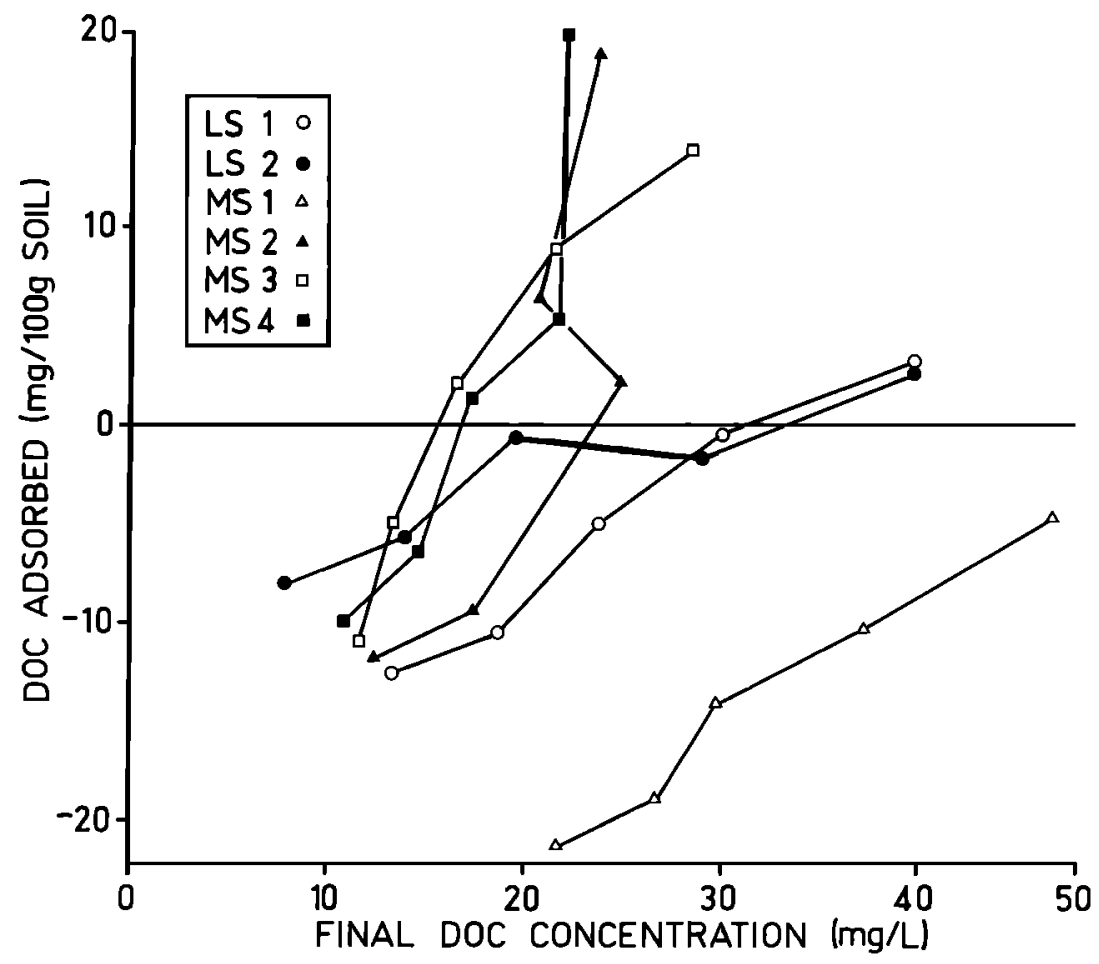

Fig. 1. Adsorption of DOC by soil samples collected in the Maimai and Larry River catchments. The notation MS1-4 and LS1-4 refer to the soil samples whose properties are described in Table 3. 
TABLE 3. Properties of Soil Samples Collected From the Maimai (M6) and Larry River (L2) Catchments

\begin{tabular}{lcccccccc}
\hline \multicolumn{1}{c}{ Sample } & $\begin{array}{c}\text { Depth, } \\
\mathrm{cm}\end{array}$ & $p \mathrm{H}$ & $\begin{array}{c}\mathrm{Fe}_{\mathrm{o}}, \\
\%\end{array}$ & $\begin{array}{c}\mathrm{Al}_{\mathrm{o}}, \\
\%\end{array}$ & $\begin{array}{c}\mathrm{Fe}_{\mathrm{p}}, \\
\%\end{array}$ & $\begin{array}{c}\mathrm{Al}_{\mathrm{p}}, \\
\%\end{array}$ & $\begin{array}{c}\mathrm{C}_{\mathrm{p}}, \\
\%\end{array}$ & $\begin{array}{c}\mathrm{C}, \\
\%\end{array}$ \\
\hline Maimai 1 & $25-35$ & 3.6 & 2.26 & 1.28 & 0.84 & 1.40 & 3.53 & 5.19 \\
Maimai 2 & $35-40$ & 4.0 & 2.65 & 2.24 & 0.86 & 2.50 & 3.63 & 3.99 \\
Maimai 3 & $45-50$ & 4.0 & 2.55 & 2.40 & 1.23 & 2.20 & 2.18 & 4.39 \\
Maimai 4 & Iron pan & 4.0 & 2.29 & 2.72 & 0.50 & 1.20 & 3.10 & 3.27 \\
Larry River 1 & 20-30 & 3.2 & 0.02 & $\mathbf{0 . 0 6}$ & 0.02 & $\mathbf{0 . 0 5}$ & $\mathbf{0 . 9 8}$ & 2.83 \\
Larry River 2 & $35-40$ & 3.1 & 0.01 & $\mathbf{0 . 0 6}$ & $\mathbf{0 . 0 2}$ & $\mathbf{0 . 0 7}$ & $\mathbf{0 . 6 3}$ & $\mathbf{0 . 9 2}$ \\
\hline
\end{tabular}

The $p \mathrm{H}$ is given in $0.01 \mathrm{M} \mathrm{CaCl}_{2} ; \mathrm{Fe}_{\mathrm{o}}$ and $\mathrm{Al}_{\mathrm{o}}$, oxalate-extractable $\mathrm{Fe}$ and $\mathrm{Al} ; \mathrm{Fe}_{\mathrm{p}}, \mathrm{Al}_{\mathrm{p}}$, and $\mathrm{C}_{\mathrm{p}}$, pyrophosphate-extractable $\mathrm{Fe}, \mathrm{Al}$, and $\mathrm{C}$; $\mathrm{C}$, total organic $\mathrm{C}$.

tory experiments which determined DOC concentrations in equilibrium with subsoil samples. The results showed that 3 of the 4 subsoil samples taken from the undisturbed forest site in catchment M6 had equilibrium DOC concentrations ranging from 15 to $20 \mathrm{mg} / \mathrm{L}$ (Figure 1). The soils were able to adsorb large amounts of DOC in response to relatively small increases in solution concentration, over the range of 10-30 $\mathrm{mg} / \mathrm{L}$ DOC. The fourth sample was the uppermost (from a depth of 25-35 cm) and had a DOC equilibrium concentration greater than the $42 \mathrm{mg} / \mathrm{L}$ used in the initial solution. By contrast, the ability of the two Larry River samples to adsorb DOC was much weaker, with equilibrium DOC concentrations of $30-40 \mathrm{mg} / \mathrm{L}$ [see Moore and Jackson, this issue].

Chemical analysis of the 6 soil samples showed that they were very acid (Table 3 ). The Maimai samples contained high $(0.5-2.7 \%)$ concentrations of oxalate- and pyrophosphate-extractable iron and aluminum, indicating the presence of amorphous and organically bound forms, respec- tively. Maimai sample 1 , collected from a depth of $25-35 \mathrm{~cm}$, contained the lowest amount of extractable iron and aluminum in the Maimai samples and also the highest organic carbon content. The differences in properties may account for the high equilibrium concentration of DOC in this sample. The concentrations of extractable iron and aluminum in the Larry River samples were much lower $(0.01-0.07 \%)$, associated with the higher equilibrium concentrations of DOC [see Moore and Jackson, this issue].

\section{The Influence of Discharge on} Stream DOC Concentrations

Stream water DOC concentrations in the eight catchments are depicted in Figures 2 and 3, based on weekly sampling and ranged from 3 to $20 \mathrm{mg} / \mathrm{L}$. In general, DOC concentrations tended to be lower in the winter (from May to September) than at other times.

DOC concentrations increased with increasing discharge, as illustrated for the streams draining the M5 and M6

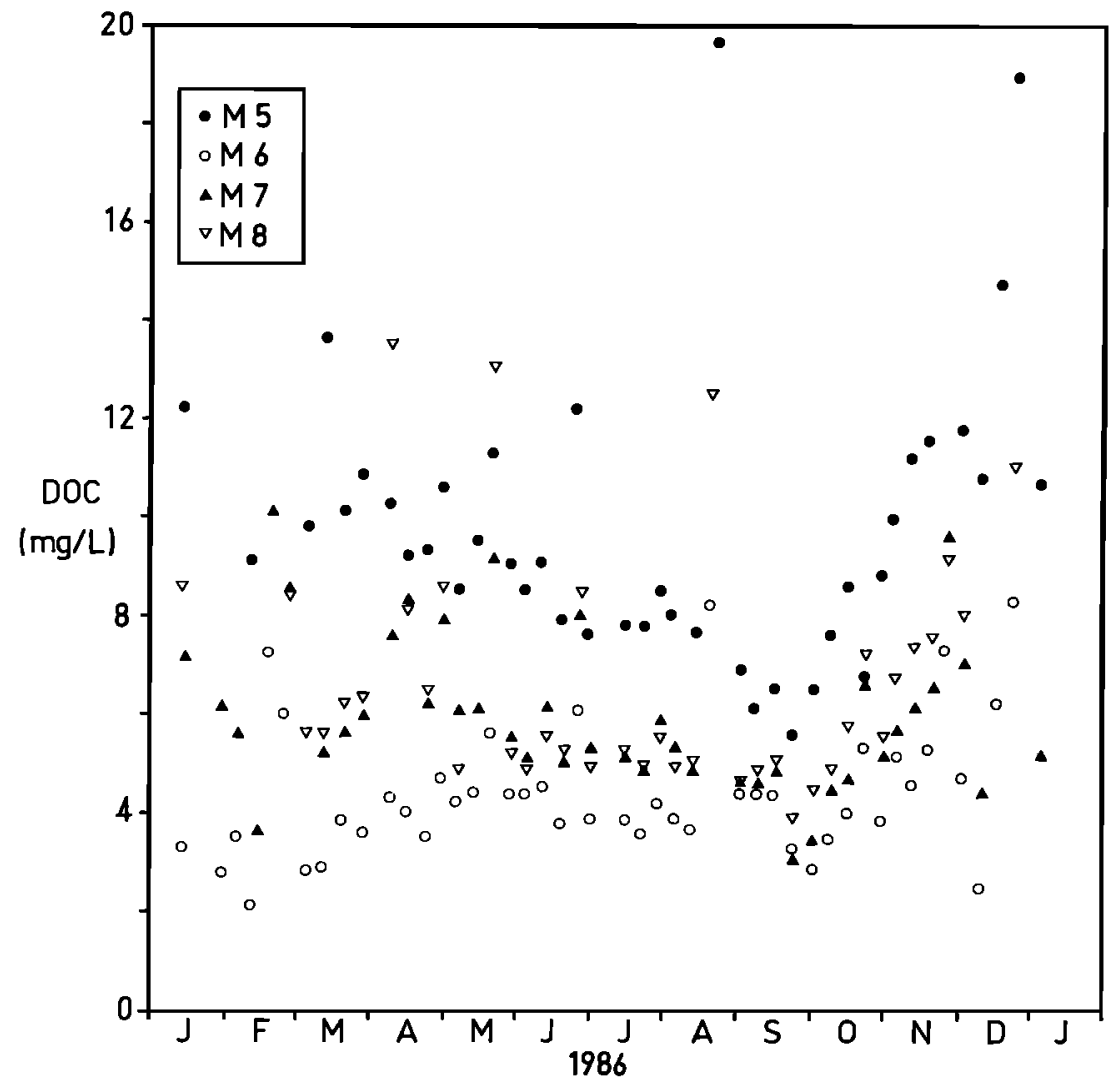

Fig. 2. DOC concentrations in streams draining catchments M5, M6, M7, and M8, based on weekly sampling. 


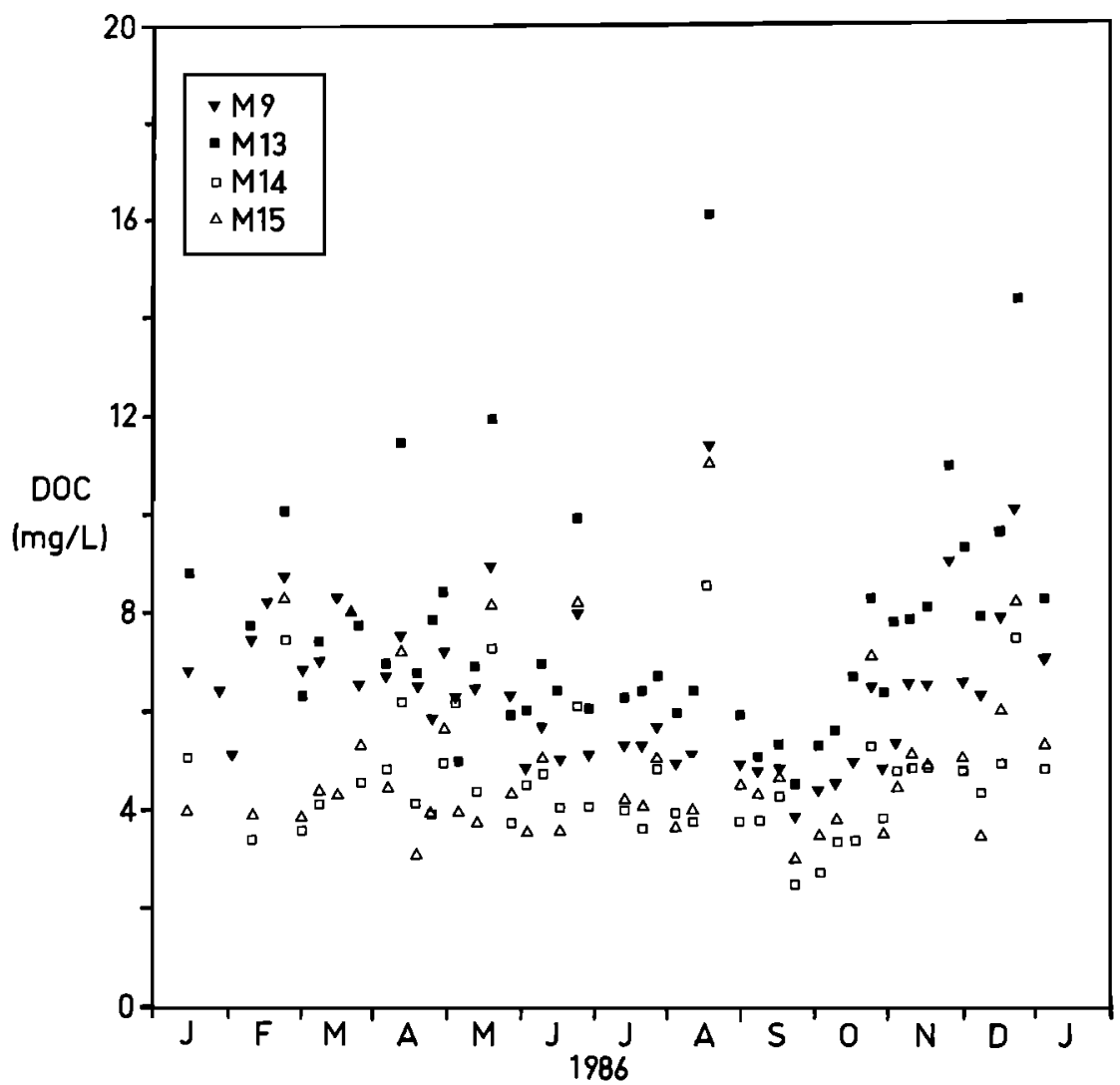

Fig. 3. DOC concentrations in streams draining catchments M9, M13, M14, and M15, based on weekly sampling.

catchments (Figure 4). Although there was a strong ( $p<$ $0.05)$ positive correlation between DOC and the logarithm of discharge for each of the eight catchments (Table 4), the small proportion of variance in DOC predicted from the logarithm of discharge ( $r^{2}$ values ranging from 0.08 to 0.66 ) suggests that factors other than discharge strongly influence stream DOC concentrations. The coefficients of determination are higher $(0.66,0.40)$ in the undisturbed catchments than those that have been clear-cut $(0.29,0.65,0.12,0.08$, $0.12,0.37$ ).

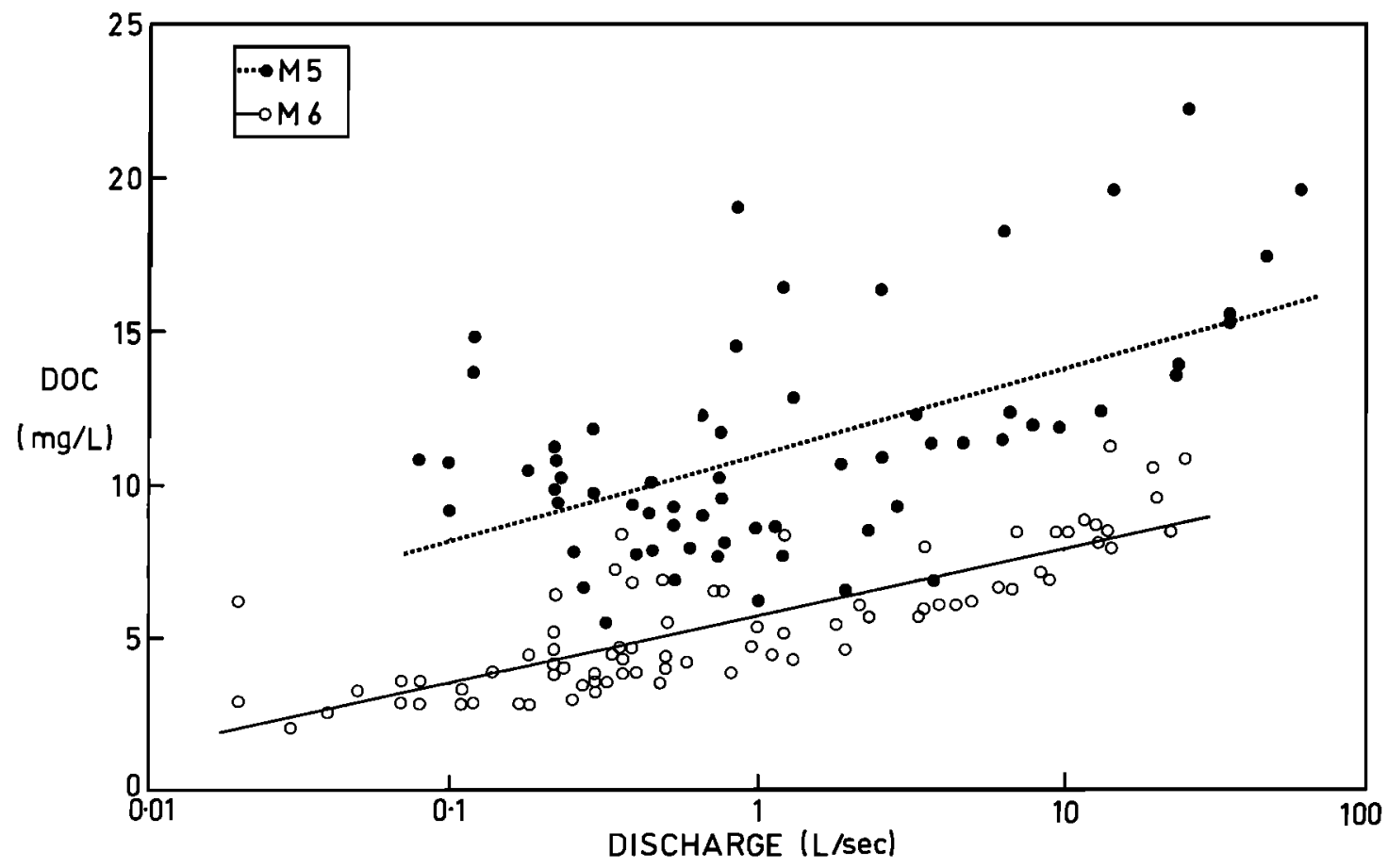

Fig. 4. The relationship between DOC and discharge in the streams draining catchments M5 and M6. The regression lines represent the logarithmic relationship defined in Table 4. 
TABLE 4. Relationship Between DOC Concentrations and Discharge $Q$ in the Eight Maimai Streams and the Estimated Export of DOC and Runoff From the Catchments in 1986

\begin{tabular}{ccccc}
\hline \multirow{2}{*}{ Catchment } & Relationship & $r^{2}$ & $\begin{array}{c}\text { Export, } \\
\mathrm{g} \mathrm{m}^{-2} \\
\mathrm{yr}^{-1}\end{array}$ & $\begin{array}{c}\text { Runoff, } \\
\mathrm{mm}\end{array}$ \\
\hline M5 & DOC $=2.67 \log Q+10.9$ & $0.293^{*}$ & 21.2 & 1755 \\
M6 & DOC $=2.19 \log Q+5.7$ & $0.662^{*}$ & 8.9 & 1442 \\
M7 & DOC $=2.50 \log Q+5.6$ & $0.652^{*}$ & $\mathrm{NC}$ & $\mathrm{NC}$ \\
M8 & DOC $=1.26 \log Q+6.8$ & $0.121 \dagger$ & 10.7 & 1371 \\
M9 & DOC $=0.96 \log Q+6.1$ & $0.080^{\dagger}$ & $\mathrm{NC}$ & $\mathrm{NC}$ \\
M13 & DOC $=1.44 \log Q+7.9$ & $0.118^{\dagger}$ & 13.7 & 1482 \\
M14 & DOC $=1.18 \log Q+4.9$ & $0.367^{*}$ & 8.2 & 1413 \\
M15 & DOC $=2.01 \log Q+5.4$ & $0.401^{*}$ & 8.8 & 1412 \\
\hline
\end{tabular}

DOC concentrations are given in milligrams per liter and discharge $Q$ is given in liters per second. NC, DOC export and runoff not calculated because of errors in the runoff estimation.

$*$ Significant at $<0.001$.

$\dagger$ Significant at $<0.05$.

Results of DOC analyses of samples collected from streams draining catchments M6 and M7 during a storm event indicate that DOC concentrations differ at similar discharges, depending on whether they occurred on the rising or falling limb of the hydrograph (Figure 5). Both streams exhibited the same pattern, with DOC concentrations on the rising limb higher, by $1-2 \mathrm{mg} / \mathrm{L}$, than on the falling limb, for similar discharges.

\section{The Influence of Disturbance on DOC Concentrations and Export}

The effects forest management practices and clear-cutting on stream DOC concentrations can be inferred by examination of the results presented in Table 5. Based on the mean rank concentration of DOC or the mean DOC concentrations from weekly samples, there were distinct differences between the catchments related to forest management practices.
The highest rank and average DOC concentrations were for catchments M5 and M13 which were logged but not burned subsequently and followed by M8 and M9 which were logged and then burned but retained a riparian strip of undisturbed forest. Lower in rank and DOC concentration is M7, which was logged and burned, but no riparian strip was left. Lowest rank and DOC concentration were recorded in the 2 catchments (M6 and M15) which were left undisturbed and in M14, which was logged and burned. The unexpected position of M14 in this sequence may be caused by the occurrence of a major landslide in the catchment in December 1979, about 2 years after logging, which removed about $500 \mathrm{~m}^{3}$, or $108 \mathrm{~m}^{3} / \mathrm{ha}$ of sediment from the catchment [O'Loughlin et al., 1980]. Significantly, the landslide also removed much of the organic debris from the stream channel, leaving a stream flowing on essentially inorganic channel material.

The estimates of DOC export ranged from 8.2 to $8.9 \mathrm{~g} \mathrm{~m}^{-2}$ $\mathrm{yr}^{-1}$ in the undisturbed M6 and M15 and landslide-affected M14 catchments to up to $21.2 \mathrm{~g} \mathrm{~m}^{-2} \mathrm{yr}^{-1}$ in the most intensively treated M5 catchment (Table 4).

To test the sources of the DOC in the catchments, samples were collected on April 8 and 9, 1986, from the stream in catchments M5 and M6, representing clear-cut and undisturbed, respectively (Figure 6). The results revealed that in catchment M6, there was no significant change in DOC concentration along the stream channel, but there was a pronounced increase, from 6 to $10 \mathrm{mg} / \mathrm{L} \mathrm{DOC}$, as the stream in M5 passed from the headwaters to the weir. This pattern suggests that stream organic debris plays a major role in controlling DOC concentrations above that supplied by water draining the surrounding soils.

\section{Discussion}

\section{DOC Flux in Maimai Catchments}

The results of this study at Maimai revealed that concentration and flux of DOC in precipitation is low, but higher in

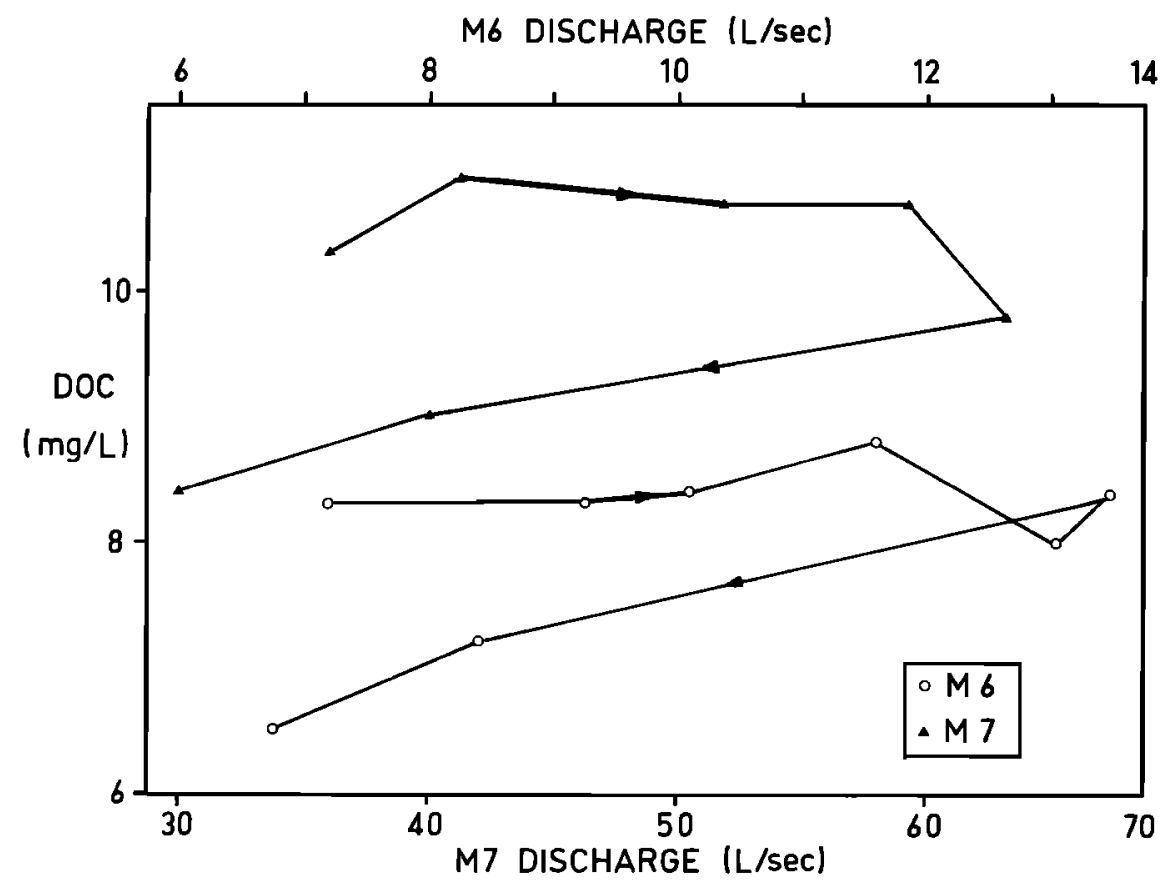

Fig. 5. Changes in DOC concentrations in streams draining catchments M6 and M7 during a storm sampled on August $19,1986$. 
TABLE 5. The Effect of Management Practices on Stream DOC Concentrations in the Maimai Catchments 1986 Based on the Weekly Samples

\begin{tabular}{cccl}
\hline Catchment & Mean Rank & $\begin{array}{c}\text { Mean DOC, } \\
\text { mg/L }\end{array}$ & \multicolumn{1}{c}{ Treatment } \\
\hline M5 & $1.1(0.6)$ & $10.2(3.2)$ & logged, not burned, desiccant applied \\
M13 & $2.2(0.6)$ & $7.9(2.4)$ & logged, not burned, riparian strip \\
M8 & $3.8(1.1)$ & $6.7(2.4)$ & logged, burned, riparian strip \\
M9 & $3.9(0.9)$ & $6.6(1.6)$ & logged, burned, riparian strip \\
M7 & $4.4(1.1)$ & $6.0(1.6)$ & logged, burned \\
M15 & $6.4(1.3)$ & $5.1(1.7)$ & undisturbed \\
M14 & $6.9(0.9)$ & $4.8(1.3)$ & logged, burned, landslide \\
M6 & $7.2(1.0)$ & $4.5(1.5)$ & undisturbed \\
\hline
\end{tabular}

Standard deviations of the rank and mean are in parentheses.

throughfall and stemflow, which amount to about $45 \mathrm{~g} \mathrm{DOC}$ $\mathrm{m}^{-2} \mathrm{yr}^{-1}$ in the undisturbed Maimai forest. The extremely high concentrations of DOC in stemflow appear to be related to the presence on beech stems of scale insects (Ultracoelostroma assimile) which exude honeydew and allow the development of sooty mold fungi [Crozier, 1982]. Stemflow from insect-infested trees was usually dark brown and contained up to $3000 \mathrm{mg} \mathrm{DOC} / \mathrm{L}$; Gaze and Clout [1983] showed that beech honeydew can contain between 20 and $80 \mathrm{~g}$ of sugar per $100 \mathrm{~g}$ of solution. Although concentrations of DOC in stemflow are very high and variable, their significance in terms of flux is reduced because of the low volume of precipitation entering the catchment as stemflow, compared to that water passing as throughfall $(1.5$ and $73 \%$, respectively [Rowe, 1979]). This pattern of the sources of DOC in forests confirms the observations in other temperate regions [e.g., Brinson et al., 1980; Eaton et al., 1973; Hoffman et al., 1980; Likens et al., 1982; McDowell and Likens, 1988; Meyer and Tate, 1983].

The high concentrations of DOC observed in soil organic horizons (mean of $56 \mathrm{mg} / \mathrm{L}$ ) are in the range $(10-100 \mathrm{mg} / \mathrm{L}$ DOC) of those reported for other temperate forests [e.g., Antweiler and Drever, 1983; Cronan and Aiken, 1985; David and Driscoll, 1984; Dawson et al., 1978; Foster and Grieve, 1982; McDowell and Likens, 1988; McDowell and Wood, 1984]. The high values recorded in the Maimai soils may be the result of the sampling being restricted to the February to May period or the very productive nature of the native forest [Wardle, 1984].

The pronounced decrease in DOC concentration and flux as the water passes through subsoil horizons and into the stream is a common feature of many temperate, forested systems [e.g., Dawson et al., 1978; Foster and Grieve, 1982; Meyer and Tate, 1983; McDowell and Wood, 1984]. Laboratory analyses of the Maimai soils revealed that they have low equilibrium concentrations of DOC and very high contents of extractable iron and aluminum. From a series of soil horizons from Spodosols, McDowell and Wood [1984] were able to show that equilibrium DOC concentration was correlated strongly with extractable iron and, to a lesser extent, aluminum and that addition of $\mathrm{FeCl}_{3}$ increased DOC adsorption by the soil. Dahm [1980] and McDowell [1985] also noted that amorphous aluminum and iron oxides in stream sediments had a high potential capacity for DOC adsorption and McDowell [1985] observed DOC uptake by stream sediments and organic debris. Thus the strongly weathered subsoil horizons of the Maimai soils appear to be important in retaining DOC leached from trees and soil organic matter. By contrast, the Larry River soils have very low contents of extractable iron and aluminum, high equilibrium concentrations, and high stream concentrations of DOC [Moore and Jackson, this issue].

Some evidence for the fate of DOC, presumed adsorbed by subsoil horizons, can be obtained from soil analyses. Data collected by McKie [1979] from a catchment near M6 showed that the subsurface horizons contain high concentrations of organic carbon, generally between 1.5 and $7.7 \%$ by dry weight. Using bulk density values, these figures convert into subsurface soil organic carbon contents averaging $9,400,10,500$, and $18,500 \mathrm{~g} / \mathrm{m}^{2}$ for soils in nose, sideslope, and hollow topographic positions, respectively.

Assuming that the average annual deposition of DOC in the subsoil horizons amounts to about $60 \mathrm{~g} / \mathrm{m}^{2}$, such a buildup of soil organic carbon could occur over a period of 156-308 years, or that the immobilized DOC has an average residence time of this length. Much of the DOC deposited in the subsoil horizons may have been decomposed and evolved back to the atmosphere as carbon dioxide; $M c D o w$ ell and Likens [1988] have noted microbial respiration of adsorbed DOC in subsoil horizons of the Hubbard Brook catchment. The soils on the steep slopes of the Maimai catchments are prone to erosion through soil creep and landslides, which would be a continual removal of the

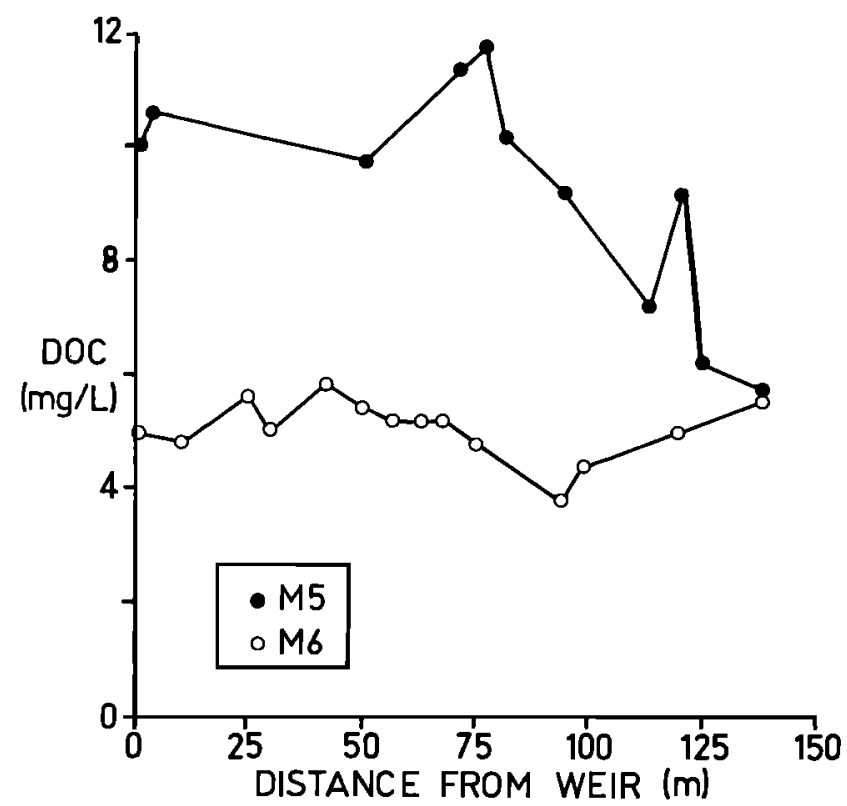

Fig. 6. DOC concentrations in the streams draining the undisturbed M6 and clear-cut M5 catchments, sampled at intervals from the weir to the headwaters. 
subsurface soil horizons enriched in DOC. O'Loughlin et al. [1982] have shown that the Maimai catchments are quite susceptible to landslides, suggesting that continual removal of the solum may also account for the low accumulation of DOC in the subsoil horizons at Maimai.

The Maimai forest has a very high biomass of about 70 $\mathrm{kg} / \mathrm{m}^{2}$ and an estimated annual litterfall of $0.6-0.8 \mathrm{~kg} / \mathrm{m}^{2}$ [Beets, 1980; Wardle, 1984]. However, the annual export of DOC from the undisturbed catchments $\left(8 \mathrm{~g} / \mathrm{m}^{2}\right)$ amounts to only about $2 \%$ of the annual litterfall, indicating the importance of terrestrial metabolism of organic matter and adsorption of DOC by the subsoil horizons.

\section{Regulation of DOC Concentrations in Maimai Streams}

The Maimai results have highlighted the importance of hydrologic conditions on stream DOC concentrations. The significant positive correlation between DOC and discharge detected in the Maimai streams has been found in several other forested, temperate catchments [e.g., Dahm, 1980; Foster and Grieve, 1982; Fisher and Likens, 1972; Grieve, $1984 a, b ;$ Meyer, 1986; Meyer and Tate, 1983; McDowell and Likens, 1988; Naiman, 1982]. The regressions indicate that an increase in discharge from 0.1 to $10 \mathrm{~L} / \mathrm{s}$ in the Maimai streams produces an increase in DOC concentration of between 1.4 and 2.6 times (average of 1.8). This scale of increase is similar to the 1.9 and 2.7 reported for a hundredfold increase in discharge in other forested catchments by Fisher and Likens [1972] in Hubbard Brook and Foster and Grieve [1982] in England, but lower than the 5.5 factor reported for a Scottish moorland catchment by Grieve [1984b].

The low proportion $(0.08-0.66)$ of the DOC variance explained by discharge in the Maimai catchments suggests that factors other than discharge are important in controlling stream water DOC concentrations. The lower proportions in the clear-cut catchments suggests that the disturbance, and the resulting changes in the channel, especially the accumulation of organic matter, may weaken the dependence of DOC on discharge.

By using season and position on the rising or falling limb of the hydrograph as additional variables, [Grieve, 1984a] increased the proportion of DOC variance explained from 0.39 with $\log$ discharge alone to 0.84 . Separation of the Maimai DOC stream data into winter and summer sets made little improvement to the regression equations, raising the $r^{2}$ value in some streams, but lowering it in others and examination of the residuals from the regressions revealed no consistent seasonal pattern. The weak dependence of stream DOC on season may be explained by the mild climate, the evergreen nature of the forest, and the year-round litterfall [Wardle, $1984]$.

Storm sampling of the Maimai streams shows that DOC concentrations are higher on the rising than the falling limb of the hydrograph, a pattern noted by McDowell and Fisher [1976] in a small, temperate, hardwood catchment in Massachusetts. However, the reverse pattern has been recorded in the Larry River catchments near Reefton [Moore and Jackson, this issue] and in a Scottish moorland stream [Grieve, 1984b]. Meyer and Tate [1983] found variable patterns in catchments at Coweeta.

Meyer and Tate [1983] postulated four main mechanisms to account for the rise in DOC concentrations with discharge and the relationship of DOC to discharge on the rising and falling limbs.

1. Throughfall onto the stream channel can add DOC, which would occur primarily on the rising limb of the hydrograph. High DOC concentrations in throughfall and higher DOC concentrations on the rising than falling limbs of the hydrograph lend support to this mechanism in the Maimai catchments.

2. DOC is leached from particulate organic matter in previously dry sections of the stream channel. Again, this is in accordance with the Maimai data.

3. DOC is released from storage in streambed intermittent channels, partially through increased turbulence associated with elevated discharge.

4. Increased amounts of DOC are released from storage sites in the terrestrial system and enter the stream via subsurface water.

The data show that DOC concentrations decrease down the soil profile from about $50 \mathrm{mg} / \mathrm{L}$ in the surface organic horizons to less $12 \mathrm{mg} / \mathrm{L}$ in the subsoil horizons. Mosley $[1979,1982]$ concluded that rapid subsurface flow in macropores, such as pipes and root channels, and seepage zones in the soil was the predominant mechanism for the generation of streamflow during storms in the Maimai catchments. However, based on isotope analysis of rainwater and streamwater, Pearce et al. [1986] and Sklash et al. [1986] concluded that storm runoff was generated primarily by transmission of "old soil water" stored in subsurface layers of the soil, with a less important contribution $(<25 \%)$ from saturated overland flow. The Maimai soils have very high infiltration capacities in the surface organic and upper mineral horizons ( 6100 and $250 \mathrm{~mm} /$ hour, respectively), precluding the generation of significant amounts of overland flow [Webster, 1977]. The narrow band of gently sloping land adjacent to the stream channel also reduces the significance of partial-area saturated overland flow to storm runoff [Pearce and McKercher, 1979].

Both of these hydrologic pathways could account for the observed DOC:discharge patterns at Maimai. The rapid movement of water through the subsoil horizons would allow DOC-rich water to circumvent adsorption of DOC by the subsoil horizons, leading to the input of relatively DOC-rich water into the stream, though this would probably tend to occur in the later stages of the storm. The "old water" hypothesis of Pearce et al. [1986] and Sklash et al. [1986] would provide the bulk of the stormflow as low-DOC water from the subsoil horizons. However, part of the storm flow would be generated by saturated overland flow on the lower slopes, mostly on the rising limb of the storm hydrograph and this would contain higher concentrations of DOC.

Average discharge-weighted concentrations of DOC in the Maimai streams range from 5.8 to $12.1 \mathrm{mg} / \mathrm{L}$ and are similar to or generally higher than those reported for other temperate, forested catchments [e.g., Cronan and Aiken, 1985; Foster and Grieve, 1982; Hobbie and Likens, 1973; McDowell and Likens, 1988; Meyer and Tate, 1983; Naiman, 1982; Schlesinger and Melack, 1981]. These high concentrations may reflect the very productive vegetation with a high biomass and its ability to produce large concentrations of DOC in stemflow and throughfall, the steep slopes in the catchments and the rapid rates of water movement and a lower capacity to immobilize DOC in the subsoils and stream channel, compared to other soils. Because of high runoff, 
export of DOC from the undisturbed catchments (M6 and M15) is considerably greater than for the other temperate, forested catchments.

Studies conducted in temperate forest catchments, such as Hubbard Brook and Coweeta [Hobbie and Likens, 1973; Meyer and Tate, 1983] have shown relatively small differences in DOC concentrations and export after clear-cutting. However, in the Andrews Experimental Forest in Oregon, Dahm [1980] noted 1.1-1.4 and 1.4-2.9-fold increases in DOC concentrations and DOC export, respectively, when comparing the 60-ha, second-order WS2 catchment covered in fir and hemlock and the clear-cut, smaller (10 ha), firstorder WS10 catchment.

The results at Maimai show that even 8-10 years after clear-cutting, concentrations and export of DOC from the clear-cut catchments are 1.2-2.4 times higher than in the undisturbed catchments. Hence there are strong associations between the forest management practices used and stream DOC concentrations in 1986, 8-10 years after the logging operations.

Reasons for this response of stream DOC to disturbance may include the following:

1. DOC concentrations in the stream could reflect differences before disturbance. Although measurements of DOC were not made before disturbance, similar predisturbance vegetation, soils, and topography of all catchments suggest that major differences in predisturbance stream DOC are unlikely. Also, the two undisturbed catchments (M6 and M15) had very similar DOC concentrations in 1986 (means of 4.5 and $4.1 \mathrm{mg} / \mathrm{L}$, respectively). There was no evidence of strong differences in other water quality parameters prior to disturbance [Neary et al., 1978].

2. The change in vegetation cover from native forest to pine and shrub may have altered the influx of DOC into the soil and stream systems.

3. Microclimatic changes associated with clear-cutting and changes in vegetation may have produced faster rates of litter and soil organic matter decomposition, thereby leading to increased fluxes of DOC into the soil and stream.

4. Hydrologic changes caused by clear-cutting, especially increased runoff, may have produced increased rates of water movement through the surface organic soil horizons, thereby circumventing DOC adsorption in the subsoil horizons.

5. Large quantities of slash and other organic debris left in the stream channel after logging may leach DOC into the stream. Stream channels in the undisturbed catchments (M6 and M15) are composed of essentially inorganic material, whereas streams in the other catchments (except M14 affected by a landslide) flow through thick (up to $1 \mathrm{~m}$ ) layers of organic debris, mainly slash left from clear-cutting.

Given the small size of and uniform treatment within each catchment, reasons $1-5$ should cause only minor changes in DOC concentration in the stream as it passes from the headwaters to the weir at the foot of the catchment. Alternatively, if reason (5) is important, there should be a significant increase in stream water DOC concentrations, from the headwaters to the weir. This is confirmed by the significant increase in DOC concentrations in the stream of disturbed catchment M5, from the headwaters to the outlet, whereas the undisturbed catchment M6 retained similar DOC concentrations throughout its length. Although the pathways that water takes and the DOC-adsorption capacity of the Maimai subsoil horizons are significant, the amount of slash and other organic debris left in the stream channel appear to be major factors controlling stream DOC. Thus management practices which affect the stream channel and riparian zone have important effects on DOC concentrations and export.

Acknowledgments. The author gratefully acknowledges the support and encouragement of the New Zealand Forest Research Institute, Christchurch, and its staff, especially J. Gray, R. J. Jackson, S. Kitchingman, A. J. Pearce, and L. K. Rowe. K. J. Collier analyzed some samples and made extremely useful comments on a draft. The Department of Geography, University of Canterbury, provided a very hospitable environment for a sabbatical leave. Partial support was provided by the Natural Sciences and Research Council of Canada through Operating and Travel grants.

\section{REFERENCES}

Antweiler, R. C., and J. I. Drever, The weathering of a late Tertiary volcanic ash: Importance of organic solutes, Geochim. Cosmochim. Acta, 47, 623-629, 1983.

Beets, P. N., Amount and distribution of dry matter in a mature beech/podocarp community, N. Z. For. Sci., 10, 395-418, 1980.

Brinson, M. M., H. D. Bradshaw, R. N. Holmes, and J. B. Elkins, Litterfall, stemflow, and throughfall nutrient fluxes in an alluvial forest swamp, Ecology, 61, 827-835, 1980.

Cronan, C. S., and G. R. Aiken, Chemistry and transport of soluble humic substances in forested watersheds of the Adirondack Park, New York, Geochim. Cosmochim. Acta, 49, 1697-1705, 1985.

Crozier, L. R., Beech honeydew: Forest produce, N. Z. J. For., 26, 200-209, 1982.

Dahm, C. N., Studies on the distribution and fates of dissolved organic carbon, Ph.D. thesis, 145 pp., Oreg. State Univ., Corvallis, 1980.

Dann, M. S., J. A. Lynch, and E. S. Corbett, Comparison of methods for estimating sulfate export from a forested watershed, J. Environ. Qual., 15, 140-145, 1986.

David, M. B., and C. T. Driscoll, Aluminum speciation and equilibria in soil solutions of a Haplorthod in the Adirondack Mountains (New York, U.S.A.), Geoderma, 33, 297-318, 1984.

Davies-Colley, R. J., and W. N. Vant, Absorption of light by yellow substance in freshwater lakes, Limnol. Oceanog., 32, 416-425, 1987.

Dawson, R., F. C. Ugolini, B. F. Hrutfiord, and J. Zachara, Role of soluble organics in the soil processes of a Podzol, Central Cascades, Washington, Soil Sci., 126, 290-296, 1978.

Eaton, J. S., G. E. Likens, and F. H. Bormann, Throughfall and stemflow chemistry in a northern hardwood forest, J. Ecol., 61, 495-508, 1973.

Eshleman, K. N., and H. F. Hemond, The role of organic acids in the acid-base status of surface waters at Bickford Watershed, Massachusetts, Water Resour. Res., 21, 1503-1510, 1985.

Fisher, S. G., and G. E. Likens, Stream ecosystem: Organic energy budget, BioScience, 27, 33-35, 1972.

Foster, I. D. L., and I. C. Grieve, Short term fluctuations in dissolved organic matter concentrations in streamflow draining a forested watershed and their relationship to the catchment budget, Earth Surf. Processes Landforms, 7, 417-425, 1982.

Gaze, A. D., and M. N. Clout, Honeydew and its importance to birds in beech forests of South Island, New Zealand, N. Z. J. Ecol., 6, 33-37, 1983.

Grieve, I. C., Concentrations and annual loading of dissolved organic matter in a small moorland stream, Freshw. Biol., 14, 533-537, 1984a.

Grieve, I. C., Relationships among dissolved organic matter, iron and discharge in a moorland stream, Earth Surf. Processes Landforms, 9, 35-41, $1984 b$.

Hobbie, J. E., and G. E. Likens, Output of phosphorus, dissolved organic carbon, and fine particulate carbon from Hubbard Brook watersheds, Limnol. Oceanogr., 18, 734-742, 1973.

Hoffman, W. A., S. E. Lindberg, and R. R. Turner, Some observations of organic constituents in rain above and below a forest canopy, Environ. Sci. Technol., 14, 999-1002, 1980.

Johnson, A. H., Estimating solute transport in streams from grab samples, Water Resour. Res., 15, 1224-1228, 1979. 
Kerekes, J., S. Beauchamp, R. Tordon, C. Tremblay, and T. Pollock, Organic versus anthropogenic acidity in tributaries of the Kejimkujik watersheds in western Nova Scotia, Water Air Soil Pollut., 31, 165-173, 1986.

Likens, G. E., E. S. Edgerton, and J. N. Galloway, The composition and deposition of organic carbon in precipitation, Tellus, 35, 16-24, 1982 .

McDowell, W. H., Kinetics and mechanisms of dissolved organic carbon retention in a headwater stream, Biogeochemistry, 1 , 329-352, 1985.

McDowell, W. H., and S. G. Fisher, Autumnal processing of dissolved organic matter in a small woodland stream ecosystem, Ecology, 57, 561-569, 1976.

McDowell, W. H., and G. E. Likens, Origin, composition, and flux of dissolved organic carbon in the Hubbard Brook valley, Ecol. Monogr., 58, 177-195, 1988.

McDowell, W. H., and T. Wood, Podzolization: Soil processes control organic carbon concentrations in stream water, Soil Sci., 137, 23-32, 1984.

McKeague, A. J., Manual on Soil Sampling and Methods of Analysis, Canadian Society of Soil Science, Ottawa, Ontario, 1978.

McKie, D. A., A study of soil variability within the Blackball hill soils, Reefton, New Zealand, M. Agr. Sci., Lincoln Coll., Canterbury, New Zealand, 1979.

Meyer, J. L., Dissolved organic carbon dynamics in two subtropical blackwater rivers, Arch. Hydrobiol., 108, 119-134, 1986.

Meyer, J. L., and C. M. Tate, The effects of watershed disturbance on dissolved organic carbon dynamics of a stream, Ecology, 64, 33-44, 1983.

Moore, T. R., The spectrophotometric determination of dissolved organic carbon in peat waters, Soil Sci. Soc. Am. J., 49, 15901592,1985

Moore, T. R., An assessment of a simple spectrophotometric method for the determination of dissolved organic carbon in freshwaters, N. Z. J. Mar. Freshw. Res., 21, 585-589, 1987.

Moore, T. R., and R. J. Jackson, Dynamics of dissolved organic carbon in forested and disturbed catchments, Westland, New Zealand, 2, Larry River, Water Resour. Res., this issue.

Mosley, M. P., Streamflow generation in a forested watershed, New Zealand, Water Resour. Res., 15, 795-806, 1979.

Mosley, M. P., Subsurface flow velocities through selected forest soils, South Island, New Zealand, J. Hydrol., 55, 65-92, 1982.

Naiman, R. J., Characteristics of sediment and organic carbon export from pristine boreal forest watersheds, Can. J. Fish Aquat. Sci., 39, 1699-1718, 1982.

Neary, D. G., A. J. Pearce, C. L. O'Loughlin, and L. K. Rowe, Management impacts on nutrient fluxes in beech-podocarphardwood forests, N.Z. J. Ecol., I, 19-26, 1978.

Nodvin, S. C., C. T. Driscoll, and G. E. Likens, Simple partitioning of anions and dissolved organic carbon in a forest soil, Soil Sci., I42, 27-35, 1986.

Oliver, B. G., E. M. Thurman, and R. L. Malcolm, The contribution of humic substances to the acidity of colored natural waters, Geochim. Cosmochim. Acta, 47, 2031-2035, 1983.

O'Loughlin, C. L., L. K. Rowe, and A. J. Pearce, Sediment yields from small forested catchments, north Westland-Nelson, New Zealand, J. Hydrol. (N.Z.), 17, 1-15, 1978

O'Loughlin, C. L., L. K. Rowe, and A. J. Pearce, Sediment yield and water quality responses to clearfelling of evergreen mixed forests in western New Zealand, Proceedings of the Helsinki Symposium, June 1980, Publ. 130, pp. 285-192, Int. Assoc. Hydrol. Sci., Gentbrugge, Belgium, 1980.

O'Loughlin, C. L., L. K. Rowe, and A. J. Pearce, Exceptional storm influences on slope erosion and sediment yield in small forest catchments, North Westland, New Zealand, in Proceedings of National Symposium on Forest Hydrology, Melbourne, Aus tralia, pp. 84-91, The Institution of Engineers, Canberra, Australia, 1982.

Pearce, A. J., and A. I. McKercher, Upstream generation of storm runoff, in Physical Hydrology-New Zealand Experience, edited by D. L. Murray and P. Ackroyd, pp. 165-192, New Zealand Hydrological Society, Wellington, 1979.

Pearce, A. J., and L. K. Rowe, Forest management effects on interception, evaporation, and water yield, J. Hydrol. (N.Z.), 18, $73-89,1979$.

Pearce, A. J., C. L. O'Loughlin, and L. K. Rowe, Hydrologic regime of small, undisturbed catchments, North Westland, New Zealand, Inf. Ser. 126, pp. 150-158, Dep. of Sci. and Ind. Res., Wellington, New Zealand, 1976

Pearce, A. J., C. L. O'Loughlin, and L. K. Rowe, Effects of clearfelling and slash burning on water yield and storm hydrographs in evergreen mixed forests, western New Zealand, Proceedings of the Helsinki Symposium, June 1980, Publ. 130, pp. 119-127, Int. Assoc. Hydrol. Sci., Gentbrugge, Belgium, 1980.

Pearce, A. J., M. K. Stewart, and M. G. Sklash, Storm runoff in humid headwater catchments, $I$, Where does the water come from?, Water Resour. Res., 22, 1263-1272, 1986.

Reuter, J. H., and E. M. Perdue, Importance of heavy metal-organic matter interactions in natural waters, Geochem. Cosmochim. Acta, 41, 325-334, 1977.

Ross, C. W., G. Mew, and P. L. Searle, Soil sequences on two terrace systems in the North Westland area, New Zealand, $N$. $Z$. J. Sci., 20, 231-244, 1977.

Rowe, L. K., Rainfall interception by a beech-podocarp-hardwood forest near Reefton, North Westland, New Zealand, J. Hydrol. (N.Z.) , 18, 63-72, 1979.

Rowe, L. K., A rainfall-runoff model for interpreting the hydrological consequences of forest management practices on small catchments, Westland, New Zealand, M. Philos. thesis, Griffith Univ., Brisbane, Australia, 1986.

Schlesinger, W. H., and J. M. Melack, Transport of organic carbon in the world's rivers, Tellus, 33, 172-187, 1981.

Sklash, M. G., M. K. Stewart, and A. J. Pearce, Storm runoff generation in humid headwater catchments, 2, A case study of hillslope and low-order stream response, Water Resour. Res., 22, 1273-1282, 1986.

Stewart, A. J., and R. G. Wetzel, Dissolved humic materials: photodegradation, sediment effects, and reactivity with phosphate and calcium carbonate precipitation, Arch. Hydrobiol., 92, 265286,1981 .

Tate, C. M., and J. L. Meyer, The influence of hydrologic conditions and successional state on dissolved organic carbon export from forested watersheds, Ecology, 64, 25-32, 1983.

Thurman, E. M., Organic Geochemistry of Natural Waters, M. Nijhoff/W. Junk Publishers, Boston, Mass., 1985.

Wardle, J. A., The New Zealand Beeches, Ecology, Utilization and Management, New Forest Service, Wellington, N.Z., 1984.

Webster, J., The hydrologic properties of the forest floor under beech/podocarp/hardwood forest, North Westland, M.S. thesis, 77 pp., Univ. of Canterbury, Christchurch, N.Z., 1977.

T. R. Moore, Department of Geography, McGill University, 805 Sherbrooke Street West, Montreal, Quebec, Canada H3A 2K6.

(Received May 9, 1988; revised January 23, 1989; accepted February 8, 1989.) 